\title{
ANALISIS KANDUNGAN KADAR SERAT DAN KARAKTERISTIK SOSIS TEMPE DENGAN FORTIFIKASI KARAGENAN SERTA PENGGUNAAN TEPUNG TERIGU SEBAGAI BAHAN PENGIKAT
}

\section{ANALYSIS OF THE CONTENT OF THE FIBERS AND THE CHARACTERISTICS OF TEMPEH SAUSAGE BY CARRAGEENAN FORTIFICATION AND USING WHEAT FLOUR AS A FASTENER}

\author{
Kiki Larasati1), Patang') dan Lahming ${ }^{3)}$ \\ 1)Alumni Program Studi Pendidikan Teknologi Pertanian FT UNM \\ 2) dan ${ }^{3)}$ Dosen Fakultas Teknik FT UNM \\ kikilarasati1995@gmail.Com
}

\begin{abstract}
ABSTRAK
Penelitian ini bertujuan untuk mengetahui pengaruh konsentrasi tepung terigu sebagai bahan pengikat terhadap karakteristik (warna, aroma, rasa dan tekstur) dan konsentrasi karagenan terhadap nilai gizi (kadar karbohidrat, kadar protein dan kadar serat sosis tempe. Penelitian ini terdiri atas dua tahap yaitu tahap I dengan perlakuan penggunaan tepung terigu $0 \%, 6 \%, 8 \%$ dan $10 \%$. Perlakuan terbaik yaitu $10 \%$ dan selanjutnya digunakan pada penelitian tahap II dengan perlakuan fortifikasi karagenan $0 \%$, $2 \%, 4 \%$ dan $6 \%$. Penelitian ini menggunakan Rancangan Acak Lengkap (RAL) dengan tiga ulangan. Hasil penelitian menunjukan konsentrasi tepung terigu yang memperlihatkan hasil terbaik adalah konsentrasi $10 \%$, sedangkan konsentrasi karagenan terbaik berdasarkan syarat mutu sosis yaitu sebesar $2 \%$ pada uji organoleptik, uji kadar serat dan uji protein kecuali uji karbohidrat yaitu pada perlakuan tanpa fortifikasi karagenan.
\end{abstract}

Kata Kunci: sosis tempe, tepung terigu, karagenan, karakteristik, nilai gizi

\section{ABSTRACT}

The objective of the research is to determine the effect of the concentration of the wheat flour as a binder on the characteristics (colour, aroma, taste and texture) and the concentration of carrageenan on the value of nutrients (carbohydrate, protein content and fibber content sausage tempeh) this research employs two steps: the first by treatment with the use of flour $0 \%, 6 \%, 8 \%$ and $10 \%$, and the best treatment is $10 \%$, and then used in the step II with treatment fortification carrageenan $0 \%, 2 \%, 4 \%$ and $6 \%$. This research use complete random with three replications. The results showed the concentration of fluorine showed the best result is a concentration of $10 \%$, whereas the concentration of carrageenan sausage the which is $2 \%$ on the organoleptic test, test and test fiber carbohydrate protein content test except the treatment on carrageenan without fortification. Keywords: Tempeh sausage, flour, carrageenan, characteristics, nutritional value 


\section{PENDAHULUAN}

Sosis merupakan makanan yang sudah familiar dikonsumsi oleh semua orang baik anak-anak, remaja, dewasa maupun orang tua. Sosis yang banyak dijumpai di masyarakat adalah sosis dengan bahan baku daging yang digiling. Pada umumnya sosis dibuat dari daging sapi, daging ayam, daging babi, daging kelinci dan ikan.

Daging banyak mengandung asam lemak jenuh yang jika dikonsumsi secara berlebihan akan menyebabkan penyumbatan pembuluh darah atau aterosklerosis. Oleh sebab itu, saat ini sedang dikembangkan sosis dari bahan nabati seperti tempe yang diharapkan mampu memenuhi kebutuhan konsumsi sosis tanpa mengurangi nilai gizi dari sosis pada umumnya yaitu kandungan protein.

Indonesia merupakan negara produsen tempe terbesar di dunia dan menjadi pasar kedelai terbesar di Asia. Sebanyak $50 \%$ dari konsumsi kedelai Indonesia dilakukan dalam bentuk tempe, $40 \%$ tahu, dan $10 \%$ dalam bentuk produk lain (seperti tauco, kecap, dan lain-lain). Konsumsi tempe rata-rata per orang per tahun di Indonesia saat ini diduga sekitar 6,45 kg (Mayasari, 2010).

Tempe merupakan sumber protein potensial dari nilai gizi yang seimbang protein hewani daging sapi dengan harga relatif murah, ketersediaan melimpah, dan tekstur yang menyerupai daging. Selain itu, proses fermentasi menjadikannya memiliki daya cerna dan asam amino essensial relatif tinggi dibandingkan bahan dasarnya. Namun, selama ini tempe belum mampu diangkat menjadi produk yang bergengsi. Penggunaan tempe menjadi olahan sosis diharapkan dapat berkembang menjadi alternatif sajian pangan tersier yang bergizi.
Penggunaan bahan pengikat pada pembuatan sosis berfungsi untuk meningkatkan daya ikat air dan emulsifikasi lemak. Bahan pengikat yang biasa digunakan adalah tepung kedelai, tepung terigu, tepung beras, tepung jagung, tepung tapioka, tepung ubi jalar, tepung roti, tepung kentang dan susu skim. Bahan pengikat dibedakan berdasarkan kadar proteinnya, dimana bahan pengikat mengandung protein yang lebih tinggi daripada bahan pengisi. Pemilihan bahan pengikat biasanya didasarkan pada daya serap air yang baik, warna yang menarik, harga yang murah, rasa yang enak serta tidak mengganggu cita rasa sosis berdasarkan bahan bakunya.

Pemilihan tepung terigu sebagai bahan pengikat karena di antara berbagai jenis tepung yang dapat digunakan, tepung terigu memiliki kandungan protein yang tinggi. Tepung terigu terbagi atas tiga jenis yaitu tepung terigu protein tinggi (13-14\%), protein sedang (11-12\%), dan protein rendah $(11 \%)$. Adapun jenis tepung terigu yang akan digunakan dalam pembuatan sosis tempe adalah tepung terigu protein tinggi.

Karagenan merupakan getah rumput laut yang diekstraksi dengan air atau larutan alkali dari spesies tertentu dari kelas Rhodophyceae (alga merah). Telah diketahui bahwa kandungan serat pangan rumput laut adalah sekitar 33$50 \%$ bobot kering (Hernawati $d k k, 2013$ ). Aplikasi penambahan keragen dalam pembuatan sosis tempe, selain sebagai emulsifier juga diharapkan akan berkontribusi sebagai sumber serat.

Serat pangan, dikenal juga sebagai serat diet atau dietary fiber, merupakan bagian dari tumbuhan yang dapat dikonsumsi dan tersusun dari karbohidrat yang memiliki sifat resistan 
terhadap proses pencernaan dan penyerapan di usus halus manusia serta mengalami fermentasi sebagian atau keseluruhan di usus besar. Serat sangat penting dalam proses pencernaan makanan dalam tubuh.

\section{Tujuan Penelitian}

Penelitian ini bertujuan untuk mengetahui konsentrasi tepung terigu yang digunakan untuk menghasilkan sosis tempe dengan karakteristik dan kandungan kadar serat terbaik. Mengetahui keterkaitan antara proporsi karagenan dan tepung terigu terhadap kandungan kadar serat dan tingkat kesukaan karakteristik sosis tempe.

\section{METODE PENELITIAN}

Penelitian ini merupakan penelitian eksperimen dengan menggunakan Rancangan Acak Lengkap, dimana pada tahap pertama terdapat 4 perlakuan penggunaan tepung terigu $(0 \%, 6 \%, 8 \%$ dan $10 \%$ ) dengan 3 kali ulangan dan tahap kedua terdapat 4 perlakuan fortifikasi karagenan $(0 \%, 2 \%, 4 \%$ dan $6 \%$ ) dengan 3 kali ulangan sehingga perlakuan yang dicobakan adalah 12 unit pada tahap pertama dan 12 unit pada tahap kedua. Metode yang digunakan dalam menentukan desain penelitian ini masing-masing perlakuan adalah metode undian.

Peralatan yang digunakan dalam penelitian ini yaitu; timbangan analitik, blender, selongsong plastik, spoit, baskom, sendok, mixer meat, dan kompor.

Bahan yang digunakan yaitu; tempe $150 \mathrm{~g}$, karagenan $(0 \%, 2 \%, 4 \%$, $6 \%)$, tepung terigu $(0 \%, 6 \%, 8 \%, 10 \%)$, minyak nabati $40 \mathrm{~g}$, putih telur $75 \mathrm{~g}$, garam $5 \mathrm{~g}$, bawang putih $1 \mathrm{~g}$, pala 0,50 $\mathrm{g}$, MSG (vetsin) 0,50 g, merica $0,30 \mathrm{~g}$, dan air es $15 \mathrm{~g}$. \begin{tabular}{llr}
\multicolumn{2}{c}{ Tahap pertama dilakukan } \\
pembuatan sosis tempe & dengan \\
penggunaan & tepung terigu & dengan \\
berbagai & konsentrasi & untuk
\end{tabular} mendapatkan karakteristik sosis tempe yang terbaik dan mengetahui kandungan kadar serat, protein dan karbohidrat sosis tempe yaitu penghalusan tempe, pencampuran semua bumbu kecuali minyak nabati, pencampuran adonan dengan minyak nabati, pemasukan sosis ke dalam selongsong, perebusan selama 20 menit, pengukusan selama 40 menit, sosis didinginkan dan dilepaskan dari selongsong.

Tahap kedua dilakukan pembuatan sosis tempe dengan menggunakan konsentrasi tepung terigu terbaik yang diperoleh pada tahap pertama dan dilakukan fortifikasi karagenan dengan berbagai konsentrasi untuk analisis tingkat kesukaan panelis terhadap karakteristik dan nilai gizi, adapun alur pembuatannya yaitu penghalusan tempe, pencampuran semua bumbu kecuali minyak nabati, pencampuran adonan dengan minyak nabati, pemasukan sosis ke dalam selongsong, perebusan selama 20 menit, pengukusan selama 40 menit, sosis didinginkan dan dilepaskan dari selongsong.

Untuk mengetahui tingkat kesukaan responden, jenis uji organoleptik yang digunakan yaitu metode uji kesukaan (hedonik) berdasarkan tingkat kesukaannya terhadap produk meliputi warna, aroma, tekstur dan rasa dengan skala penilaian 1-5 yaitu (1) tidak suka, (2) agak suka, (3) suka, (4) sangat suka, (5) amat sangat suka, sebagai parameter penentuan suatu kesan dari suatu rangsangan yang ditimbulkan oleh produk. Data dikumpulkan dengan 
menggunakan angket (hedonic scale scoring).

Penelitian ini dilaksanakan di Laboratorium Pendidikan Teknologi Pertanian Fakultas Teknik Universitas Negeri Makassar dan Analisis kimia dilakukan di Balai Besar Industri Hasil Perkebunan Makassar.

Data pada penelitian ini diperoleh dari hasil pengujian karakteristik organoleptik dengan menggunakan metode uji hedonik (kesukaan) yang dilakukan dengan menguji seberapa jauh tingkat kesukaan panelis terhadap karakteristik sosis tempe yang meliputi tekstur, cita rasa, warna dan aroma. Panelis yang dilibatkan dalam pengujian ini yaitu panelis semi terlatih (semitrained panel) yang terdiri dari 25 orang dari kalangan mahasiswa. Data yang diperoleh dianalisis menggunakan analisis statistik sidik ragam ANOVA yang dilanjutkan dengan uji lanjut DMRT.

\section{HASIL DAN PEMBAHASAN Uji Organoleptik}

Uji organoleptik atau uji sensorik dan hedonik merupakan metode pengukuran kualitas suatu produk berdasarkan informasi yang diterima oleh lima panca indera yakni penciuman, penglihatan, perasa, peraba, dan pendengaran (Bourne 2002). Pengujian organoleptik perlu dilakukan untuk melihat tingkat penerimaan konsumen terhadap suatu produk.

\section{Tahap I}

\section{Warna}

Penentuan mutu bahan makanan pada umumnya sangat bergantung pada beberapa faktor antara lain cita rasa, warna, tekstur dan nilai gizinya. Akan tetapi, sebelum faktor-faktor lain dipertimbangkan, faktor warna merupakan karakter visual yang sangat menentukan (Winarno, 2004).

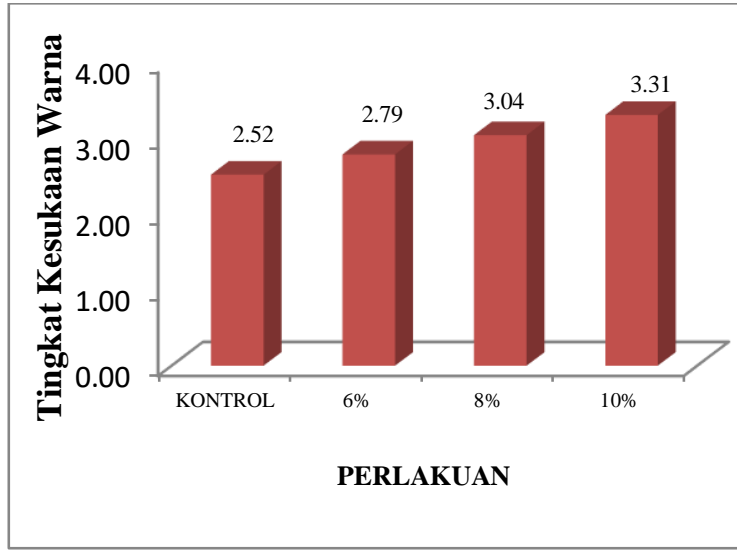

Gambar 1

Hasil Uji Hedonik Warna Sosis Tempe Tahap I

Hasil penelitian menunjukan bahwa warna sosis yang paling disukai adalah dengan pengunaan tepung terigu $10 \%$ dengan nilai 3,31 dan warna sosis dengan nilai terendah adalah dengan perlakuan tanpa penggunaan tepung terigu (kontrol) sebesar 2,52. Hal ini disebabkan penggunaan tepung terigu menghasilkan warna yang agak kecoklatan yang hampir sama dengan sosis yang beredar di pasaran. Sedangkan sosis tanpa penggunaan tepung terigu berwarna pucat sehingga tidak disukai panelis.

Pembentukan warna disebabkan adanya proses karamelisasi dan reaksi maillard. Warna kecoklatan muncul karena adanya reaksi antara karbohidrat dengan asam amino. Selama pemanasan, gugus karboksil akan bereaksi dengan gugus amino atau peptide sehingga terbentuk glikosilamin. komponen-komponen ini selanjutnya mengalami polimerisasi membentuk komponen berwarna gelap "melanoidin" yang menyebabkan perubahan warna pada produk, yaitu produk akan menjadi kecoklatan. 
Aroma

Aroma merupakan hasil rangsangan kimia dari syaraf-syaraf olfaktori yang berada di bagian akhir dari rongga hidung. Aroma merupakan bau yang dicium karena sifatnya yang mudah menguap (Pratiwi, 2008).

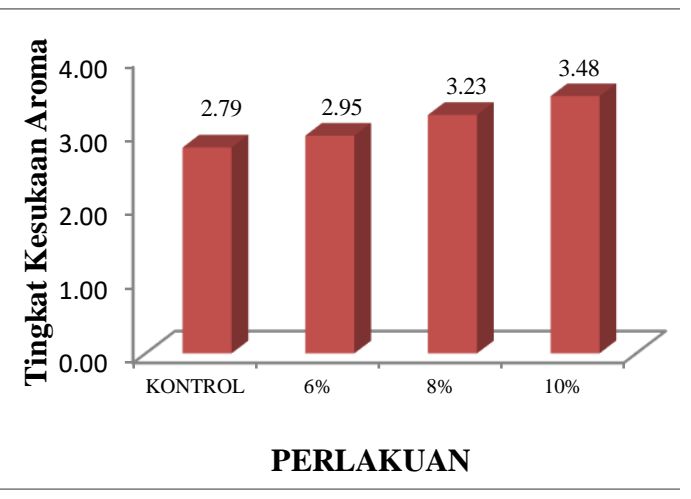

Gambar 2

Hasil Uji Hedonik Aroma Sosis Tempe Tahap I

Hasil penelitian menunjukan bahwa warna sosis yang paling disukai adalah dengan pengunaan tepung terigu $10 \%$ dengan nilai 3,48 dan warna sosis dengan nilai terendah adalah dengan perlakuan tanpa penggunaan tepung terigu (kontrol) sebesar 2,79.

Penggunaan tepung terigu 10\% akan menurunkan aroma khas tempe (Langu). Hal ini diduga, penggunaan tepung yang relatif banyak menyebabkan kandungan lemak semakin sedikit sehingga menurunkan aroma khas tempe.

\section{Rasa}

Rasa merupakan salah satu sifat sensori yang sangat penting dalam penerimaan suatu produk. Dalam suatu penelitian pangan yang menghasilkan produk untuk dikonsumsi seperti makanan, rasa diasumsikan sebagai indikator paling utama dalam pengujiannya. Makanan yang terbuat dari teknologi modern dan bernilai gizi tinggi pun bukan jaminan akan disukai oleh konsumen dari segi rasa.

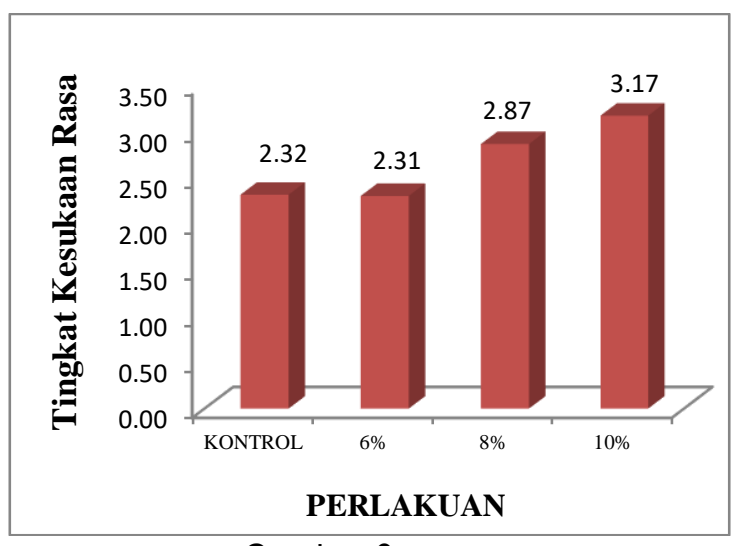

\section{Gambar 3}

Hasil Uji Hedonik Rasa Sosis Tempe tahap I

Hasil penelitian menunjukan bahwa rasa sosis yang paling disukai adalah dengan pengunaan tepung terigu $10 \%$ dengan nilai 3,17 dan rasa sosis dengan nilai terendah adalah dengan perlakuan tanpa penggunaan tepung terigu (kontrol) sebesar 2,31.

Pengaruh penggunaan tepung terigu terhadap sosis tempe disebabkan karena tepung terigu dapat menutupi rasa pahit dari tempe yang berasal dari bahan baku tempe yaitu kedelai. Hal ini sejalan dengan pendapat Sutristno Koswara dalam Mayasari (2010), bahwa rasa dari sosis tempe diduga disebakan adanya soyasaponin dan sapogenol yang merupakan penyebab rasa pahit dan rasa kapur (Bitter and Chalky Flavor) dalam kedelai.

\section{Tekstur}

Tekstur merupakan salah satu atribut mutu bahan makanan. Aspek yang dinilai pada tekstur sosis adalah kasar serta halusnya produk yang dihasilkan. Tekstur dalam penelitian ini diamati dengan menggunakan jari 
maupun menggunakan mulut dengan cara dikunyah atau digigit.

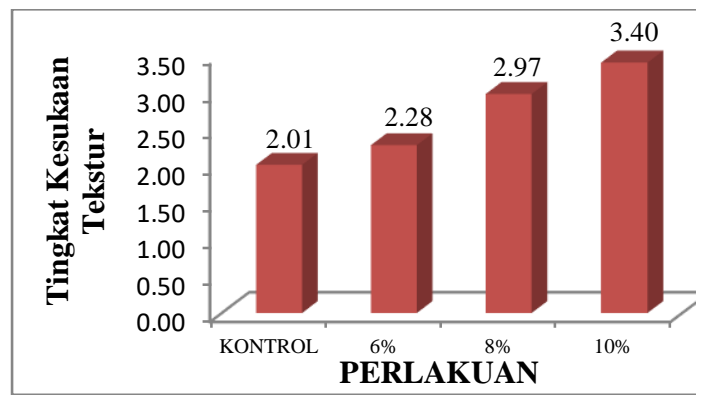

Gambar 4

Hasil Uji Hedonik Tekstur Sosis Tempe Tahap I

Hasil penelitian menunjukan bahwa tekstur sosis yang paling disukai adalah dengan pengunaan tepung terigu $10 \%$ dengan nilai 3,40 dan tekstur sosis dengan nilai terendah adalah dengan perlakuan tanpa penggunaan tepung terigu (kontrol) sebesar 2,01.

Penggunaan tepung terigu yang lebih yang lebih banyak menghasilkan tekstur yang lebih kompak dan keras. Pasaribu (2009) menyatakan bahwa protein tepung terigu mempunyai kemampuan untuk mengikat lemak dan air dimana protein tersebut akan menyelubungi lemak yang terdapat pada sosis sehingga emulsi sosis yang diperoleh lebih stabil dan tekstur lebih padat dan empuk.

\section{TAHAP ॥ \\ Warna}

warna merupakan hal yang pertama kali dilihat oleh panelis karena warna merupakan salah satu atribut penting dalam penerimaan suatu produk. Secara visual faktor warna tampil lebih dahulu dan kadang-kadang sangat menentukan. Suatu bahan yang dinilai bergizi, enak, dan teksturnya sangat baik tidak akan dimakan apabila memiliki warna yang tidak sedap dipandang atau memberi kesan telah menyimpang dari warna yang seharusnya. (Winarno, 2004).

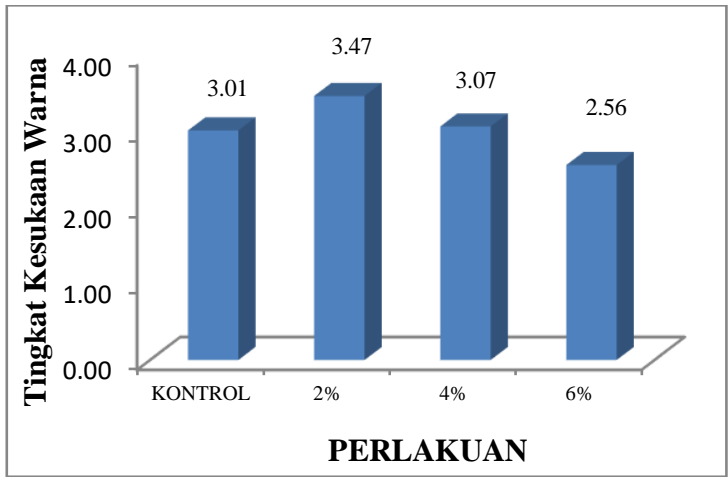

Gambar 5

Hasil Uji Hedonik Warna Sosis Tempe Tahap II

Hasil penelitian menunjukan bahwa warna sosis yang paling disukai adalah dengan pengunaan karagenan $2 \%$ dengan nilai 3,47 dan warna sosis dengan nilai terendah adalah dengan perlakuan penggunaan karagenan $6 \%$ sebesar 2,56.

penambahan karagenan memberikan warna yang kecoklatan jika dengan konsentrasi sedikit sehinggah dengan penambahan karagenan dengan konsentrasi yang banyak akan menghasilkan warna lebih gelap, tidak sedap dipandang atau memberikan kesan menyimpang dari warna sosis yang beredar di pasaran yang menyebabkan panelis tidak menyukainya.

\section{Aroma}

Aroma merupakan salah satu faktor penting bagi konsumen untuk memilih makanan. Aroma makanan banyak menentukan kelezatan suatu makanan. Aroma yang diterima hidung dan otak merupakan campuran empat bau utama yaitu harum, asam, tengik dan hangus (Sidi, dkk. 2014). 


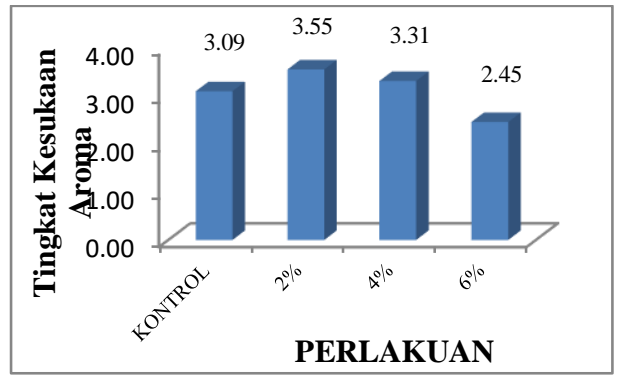

Gambar 6

Hasil Uji Hedonik Aroma Sosis Tempe Tahap II

Hasil penelitian menunjukan bahwa aroma sosis yang paling disukai adalah dengan pengunaan karagenan $2 \%$ dengan nilai 3,55 dan aroma sosis dengan nilai terendah adalah dengan perlakuan penggunaan karagenan $6 \%$ sebesar 2,45.

Semakin banyak penggunaan karagenan maka sosis tempe yang dihasilkan akan semakin beraroma amis sehingga panelis tidak menyukai. Aroma amis dari karagenan berasal dari bahan baku karagenan yaitu rumput laut. Selain itu, aroma sosis dipengaruhi oleh penambahan penyedap rasa dan bumbu-bumbu seperti lada dan bawang putih.

\section{Rasa}

Rasa merupakan faktor yang
paling penting karena akan
mempengaruhi keputusan akhir para
konsumen untuk menerima atau
menolak suatu produk makanan (Abubakar dan Aziz, 2011).

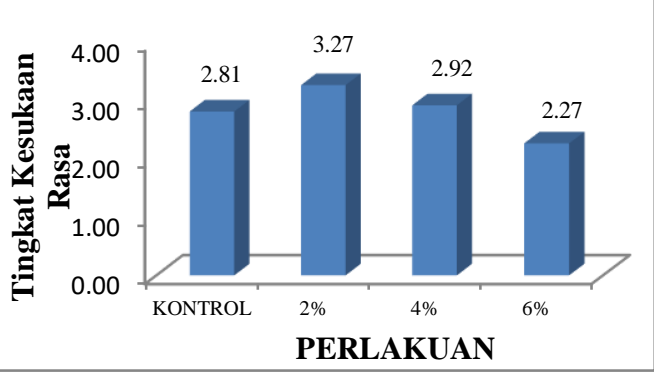

Gambar 7

Hasil Uji Hedonik Rasa Sosis Tempe

Tahap II
Hasil penelitian menunjukan bahwa rasa sosis yang paling disukai adalah dengan pengunaan karagenan $2 \%$ dengan nilai 3,27 dan rasa sosis dengan nilai terendah adalah dengan perlakuan penggunaan karagenan $6 \%$ sebesar 2,27.

Rasa yang dihasilkan dengan penambahan karagenan memberikan rasa yang asin sehingga semakin banyak konsentrasi karagenan yang ditambahkan maka rasa sosis akan semakin asin dan tidak disukai panelis.

\section{Tekstur}

Sama halnya dengan penelitian tahap 1, Tekstur dalam penelitian tahap 2 ini diamati dengan menggunakan jari dengan cara diraba dan ditekan maupun menggunakan mulut dengan cara dikunyah atau digigit.

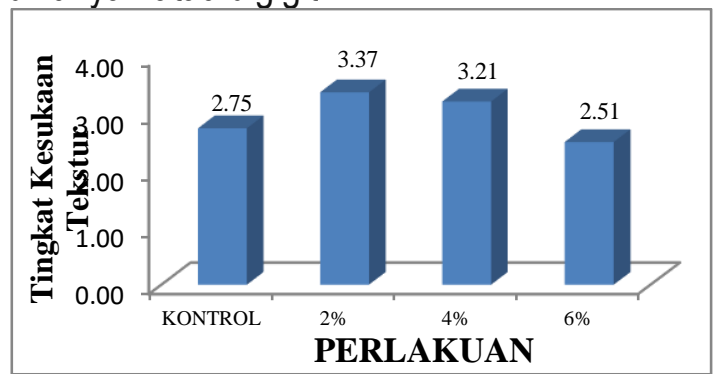

Gambar 8

Hasil Uji Hedonik tekstur Sosis Tempe Tahap II

Hasil penelitian menunjukan bahwa tektur sosis yang paling disukai adalah dengan pengunaan karagenan $2 \%$ dengan nilai 3,37 dan tekstur sosis dengan nilai terendah adalah dengan perlakuan penggunaan karagenan $6 \%$ sebesar 2,51.

Fortifikasi karagenan pada pembuatan sosis akan membuat tekstur sosis menjadi lebih halus, karena karagenan dapat berikatan dengan air secara sempurna, sehingga mampu menghomogenkan tempe yang telah dihaluskan. karagenan dapat 
meningkatkan daya mengikat air sehingga dapat memperbaiki tekstur produk. Menurut Wiraswanti (2008) dalam Rezekiana (2013) bahwa penggunaan karagenan dimaksudkan untuk memperbaiki tekstur dan kekenyalan gel produk. Penambahan karagenan dalam jumlah yang banyak mengakibatkan tekstur sosis menjadi terlalu keras dan tidak disukai oleh panelis.

\section{Kadar Serat}

Serat makanan adalah bahan dalam makanan yang berasal dari tanaman yang tahan terhadap pemecahan oleh enzim dalam saluran pencernaan sehingga tidak dapat diabsorbsi. Serat pangan tidak mengandung zat gizi, akan tetapi memberikan keuntungkan bagi kesehatan yaitu mengontrol berat badan atau kegemukan (obesitas), menanggulangi penyakit diabetes, mencegah gangguan gastrointestinal, kanker kolon (usus besar), serta mengurangi tingkat kolesterol darah dan penyakit kardiovaskuler (Santoso, 2011).

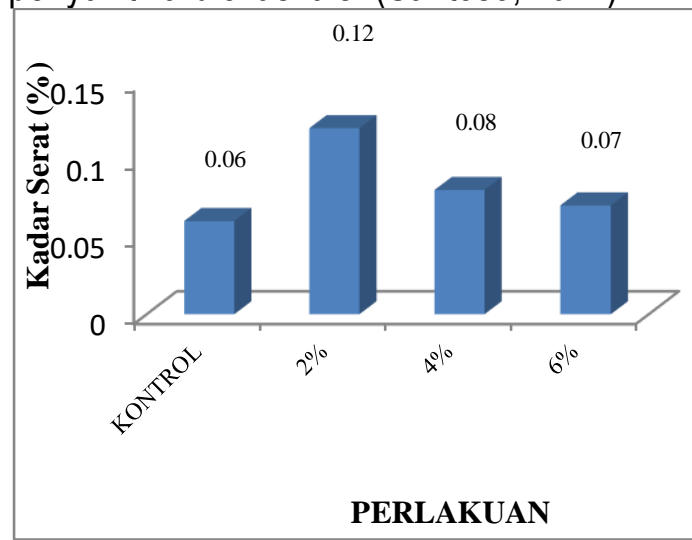

Gambar 9

Kadar Serat pada Sosis Tempe

Hasil analisis kadar serat sosis tempe dengan penambahan karagenan menunjukan bahwa kadar serat kasar yang dihasilkan sosis pada perlakuan fortifikasi karagenan $0 \%$ sebesar $0,06 \%$; fortifikasi karagenan $2 \%$ sebesar 0,12 ; fortifikasi karagenan $4 \%$ sebesar $0,08 \%$; fortifikasi karagenan $6 \%$ sebesar $0,07 \%$.

Rendahnya kadar serat sosis diduga disebabkan oleh kapang Rhizopus oligosporus yang berasal dari bahan baku tempe mampu menghasilkan enzim selulosa yang mampu mendegradasi serat kasar. Beberapa jenis Rhizopus bertumbuh dengan suhu optimum $37-50^{\circ} \mathrm{C}$ sehinggah pada saat pemasakan sosis kapang ini masih menghasilkan enzim selulase yang merupakan enzim kompleks yang bekerja secara bertahap dalam memecah selulosa (Santoso, 2011).

Semakin berkurangnya kadar serat pada perlakuan 4 dan $6 \%$ diduga disebabkan waktu analisis di laboratorium yang berbeda, dimana perlakuan 4 dan $6 \%$ dilakukan analisis masing-masing setelah 2 dan 3 minggu penyimpanan. Menurut Tillman $d k k$ (1989) dalam Sari (2015) bahwa selama penyimpanan, mikroorganisme merombak ikatan lignoselulosa yang terdapat pada lignin didalam serat kasar. Kandungan lignin pada serat kasar dapat diputuskan ikatannya oleh mikroorganisme dengan menghasilkan enzim ekstraseluler, mikroorganisme memutus ikatan lignoselulosa yang terdapat pada serat kasar seperti selulosa dan hemiselulosa menjadi glukosa sehingga bisa dimanfaatkan sebagai bahan makanan oleh mikroorganisme.

$\begin{array}{llr}\text { Menurut } & \text { Nafiah } & \text { (2011) } \\ \text { penambahan } & \text { karagenan } & \text { dapat }\end{array}$
meningkatkan kadar air. Hal ini diduga karena karagenan mengandung serat pangan tidak larut yang dapat mengikat air dan memerangkap dalam matriks setelah pembentukan gel karaginan. 
Kandungan gugus sulfat yang berada pada karagenan bermuatan negatif disepanjang rantai polimernya dan bersifat hidrofilik yang dapat mengikat air dan gugus hidroksil lainnya, sehinggah semakin banyak konsentrasi karagenan yang ditambahkan maka kadar air dalam sosis akan semakin meningkat yang kemudian berpengaruh terhadap peningkatan jumlah mikroorganisme yang menyebabkan penurunan mutu pangan.

\section{Kadar Protein}

Protein merupakan suatu zat yang penting bagi tubuh karena berfungsi sebagai zat pembangun dan pengatur. Protein adalah sumber-sumber asam amino yang mengandung unsurunsur $\mathrm{C}, \mathrm{H}, \mathrm{O}$, dan $\mathrm{N}$ yang tidak dimiliki oleh lemak atau karbohidrat. Protein juga dapat digunakan sebagai bahan bakar apabila keperluan energi tubuh untuk terpenuhi oleh karbohidrat dan lemak (Winarno dalam Mayasari, 2010).

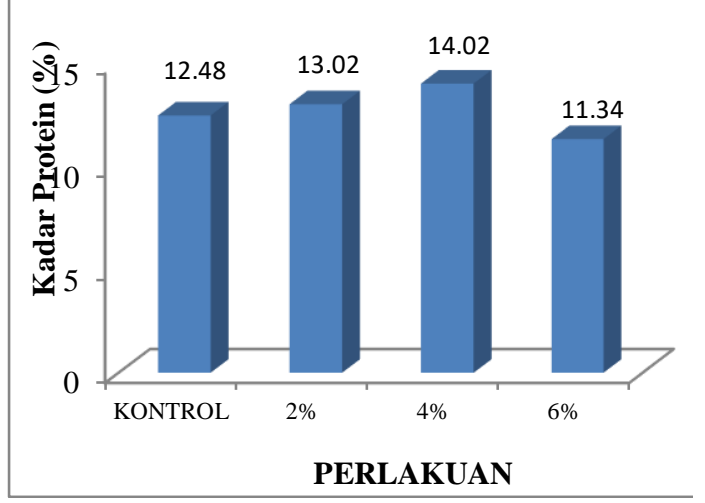

\section{Gambar 10 \\ Kadar Protein pada Sosis Tempe}

Berdasarkan hasil analisis kadar protein sosis tempe menunjukan bahwa kadar protein sosis tempe terbesar $14.02 \%$ dan sosis tempe terbaik berdasarkan karakteristik yaitu dengan fortifikasi karagenan $2 \%$ dengan kadar protein 13,02 . Nilai tersebut memenuhi standar kadar protein menurut SNI 013820-1995 yaitu minimal $13 \%$.

Perlakuan fortifikasi karagenan $4 \%$ menghasilkan sosis tempe dengan kadar protein tertinggi, hal ini disebabkan oleh fortifikasi karagenan karena Semakin banyak penambahan karagenan akan menyebabkan kadar protein sosis tempe olahan semakin meningkat (Nafiah, 2011). Kadar protein yang terendah dihasilkan oleh sosis tempe dengan perlakuan fortifikasi karagenan $6 \%$, hal ini disebabkan oleh lamanya penyimpanan sosis. Uju $d k k$ (2007) melaporkan bahwa selama penyimpanan akan terjadi pembentukan kristal es. Kristal es ini akan memecahkan jaringan dan pada saat thawing terjadi drip lose sehingga sebagian protein larut dalam air serta keluar dari sel dan terbuang. Intensitas drip lose ini akan semakin tinggi dengan semakin lama waktu penyimpanan beku tetapi dengan penggunaan karagenan dapat menurunkan tingkat penurunan kadar protein. hal ini menunjukkan bahwa karaginan memiliki efek cryoprotective pada kestabilan protein selama penyimpanan beku.

\section{Kadar Karbohidrat}

Karbohidrat merupakan sumber energi utama bagi tubuh. Karbohidrat dalam sosis sebagian besar berasal dari bahan pengisi. Karbohidrat memberikan peran yang penting antara lain berpengaruh terhadap warna, cita rasa, daya kembang dan sumber energi. Karbohidrat berguna untuk mencegah timbulnya ketosis, pemecah protein tubuh yang berlebihan, kehilangan mineral dan berguna untuk membantu metabolism lemak dan protein di dalam tubuh (Winarno dalam Fakhrudin, 2009). 


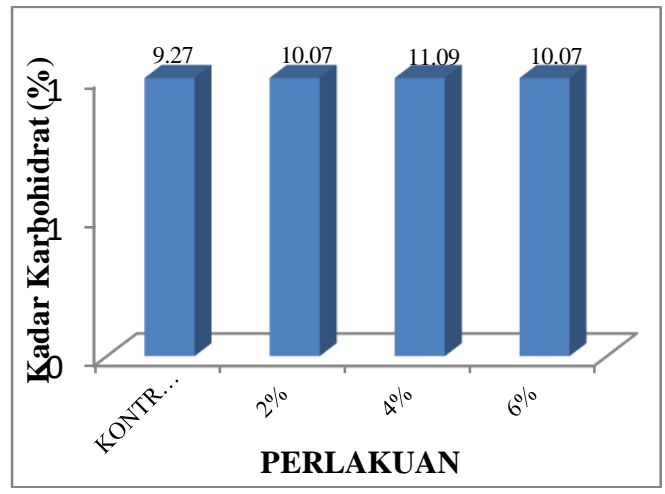

Gambar 11

Kadar Karbohidrat pada Sosis Tempe

Berdasarkan hasil analisis kadar karbohidrat sosis tempe menunjukan bahwa kadar karbohidrat sosis tempe terbesar $11,09 \%$ yang dihasil oleh perlakuan fortifikasi karagenan $4 \%$ dan sosis tempe terbaik berdasarkan karakteristik yaitu dengan fortifikasi karagenan $2 \%$ dengan kadar protein 10,07. Nilai tersebut lebih besar dari standar SNI 01-3820-1995 yaitu maksimal $8 \%$.

Kadar karbohidrat yang besar yang terkandung dalam sosis tempe sangat dipengaruhi oleh bahan pengikat yaitu tepung terigu. Perlakuan fortifikasi karagenan menghasilkan kadar karbohidrat sosis tempe yang berbeda dengan perlakuan tanpa fortifikasi karagenan. Hal ini menunjukan bahwa penambahan karagenan berpengaruh terhadap meningkatnya kadar karbohidrat sosis tempe. Sejalan dengan pendapat Abubakar dkk (2011) bahwa penambahan karagenan akan menambah jumlah karbohidrat dalam produk. Menurunnya kandungan karbohidrat pada sosis tempe fortifikasi karagenan 6\% disebabkan oleh lama penyimpanan. Selama penyimpanan akan terjadi hidrolisa pati karena enzim amylase yang mengakibatkan berkurangnya gula.

\section{KESIMPULAN}

Konsentrasi tepung terigu terbaik dalam pembuatan sosis tempe adalah $10 \%$, sedangkan karagenan sebesar $2 \%$. Dalam pembuatan sosis tempe terdapat keterkaitan antara karagenan dan tepung terigu dimana proporsi yang menghasilkan kadar serat tertinggi maupun tignkat panerimaan panelis terbaik pada perlakuan $2 \%$.

\section{DAFTAR PUSTAKA}

Abubakar, Suryati, T., dan Aziz, A. 2011. Pengaruh Penambahan Karagenan Terhadap Sifat Fisik, Kimia dan Palatabilitas Nugget Daging Itik Lokal (Anas platyrynchos). Seminar Nasional. Teknologi Peternakan dan Veteriner. IPB. Bogor

Bourne MC. 2002. Food Texture and Viscosity: Concept and Measurement. London (GB): Academic Pr

Fakhrudin, A. 2009. Pemanfaatan Air Rebus Kupang Putih (Corbula faba hinds) untuk Pengolahan Petis dengan Penambahan berbagai Pati-Patian. Bogor: Institut Pertanian Bogor

Hernawati., W. Manalu, A. Suprayogi \& D. A. Astuti. 2013. Suplementasi Serat Pangan Karagenan dalam Diet untuk Memperbaiki Parameter Lipid Darah Mencit Hiperkolesterolemia. Makara Seri Kesehatan. Vol. 17,No. 1

Mayasari, S. 2010. Kajian Karakteristik Kimia dan Sensoris Sosis Tempe Kedelai Hitam (Glycine soja) dan Kacang Merah (Phaseolus 


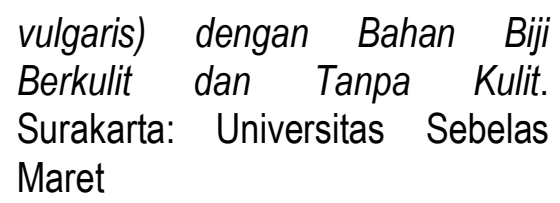

Nafiah, H. 2011. Pemanfaatan Karagenan dalam Pembuatan Nugget Ikan Cucut. Semarang: Universitas Negeri Semarang

Passaribu, D. T. Y. 2009. Pengaruh Taraf Penambahan Tepung Terigu sebagai Bahan Pengikat terhadap Kualitas Sosis Daging Ayam. Medan: Universitas Sumatra Utara

Pratiwi M.A. 2008. Pemanfaatan Tepung Hotong (Setaria italica (L) Beauv.) dan Pati Sagu dalam Pembuatan Cookies. Skripsi diterbitkan. Bogor: Departemen IImu dan Teknologi Pangan, Fakultas Teknologi Pertanian, Institut Pertanian Bogor.

Rezekiana. M, Wijana. S, Sucipto. 2015.

Pengaruh Penambahan Karagenan pada Pembuatan Nori Fungsional Lidah Buaya (Aloe barbadensis). Malang: Universitas Brawijaya

Santoso, A. 2011. Serat Pangan (Dietary Fiber) \& Manfaatnya Bagi Kesehatan. Magistra No. 75.

Winarno F.G. 2004. Kimia Pangan dan Gizi . Jakarta: Gramedia 